\section{The pharmacokinetics of etanercept in patients with heart failure}

Although the cause of disease progression is multifactorial, recent studies have demonstrated that the development of symptomatic heart failure is associated with an increase in circulating levels of the proinflammatory cytokine tumour necrosis factor (TNF) [1, 2]. Thus, investigators proposed that inhibition of TNF expression or bioavailability might have salutory effects in patients with symptomatic heart failure.

Etanercept (TNFR: Fc, Enbrel ${ }^{\circledR}$ ) is a recombinant, human, fusion protein that binds to TNF, prohibiting its proinflammatory action. After subcutaneous administration, its pharmacokinetic parameters have been characterized in healthy volunteers and patients with rheumatoid arthritis [3, 4]. It is slowly absorbed $\left(t_{\max }=51-72 \mathrm{~h}\right)$ and slowly cleared $\left(\mathrm{CL} / F=0.089-0.1371 \mathrm{~h}^{-1} ; t_{1 / 2}=68-115 \mathrm{~h}\right)$. Because of its large molecular size etanercept may be eliminated by the reticuloendothelial system of the liver or spleen [3]. Etanercept is presently undergoing evaluation as a therapeutic option for patients with heart failure in two clinical trials; one in the US (RENAISSANCE) and a second in Europe, Australia and New Zealand (RECOVER).

Heart failure can affect the pharmacokinetic characteristics of many medications, although unfortunately, not in a predictable manner $[5,6]$. The purpose of this study was to describe the pharmacokinetics of etanercept in patients with heart failure.

Eleven patients, nine males and two females, with NYHA class II-IV heart failure participated in this open-label pharmacokinetic portion of a larger study after completing a double-blind, randomized multiple-dose safety trial [7]. Their ages ranged from 31 to 74 years. Mean creatinine clearance was $99 \mathrm{ml} \mathrm{min}^{-1}$ (range $48-134 \mathrm{ml} \mathrm{min}^{-1}$ ). Concomitant medications had been stable for at least 1 month prior to randomization.

Patients had received a dose of $12 \mathrm{mg} \mathrm{m}^{-2}$ (maximum dose $25 \mathrm{mg}$ ) of etanercept (Enbrel, Immunex Corporation) by subcutaneous injection twice weekly for 12 weeks. Twice-weekly dosing necessitated uneven dosage intervals of $72 \mathrm{~h}$ and $96 \mathrm{~h}$. Care was taken that all patients be studied during a $96 \mathrm{~h}$ dosing interval. Serial serum samples were collected by separate venipuncture before and at 2, 4, 12, 24, 36, 48, 60, 72, and $96 \mathrm{~h}$ after drug administration. Each sample was immediately centrifuged in the cold and the supernatant removed and frozen.

Etanercept serum concentrations were measured using an ELISA method with a limit of quantification of $0.3 \mathrm{ng} \mathrm{ml}{ }^{-1}$. The coefficient of variation for the quality controls was less than 7\%. Adequate storage stability had been previously demonstrated.

The serum concentration data were analysed using a noncompartmental method [8]. The maximum serum concentration $\left(C_{\max }\right)$ and $t_{\max }$ were determined directly from the observed concentration data. The area under the concentration-time curve (AUC) was calculated using the linear trapezoidal rule. Apparent clearance after oral administration $(\mathrm{CL} / F)$ was calculated as a ratio of dosing rate to AUC. Summary statistics were calculated for concentration and for $C_{\max }, t_{\max }, \mathrm{AUC}$, and $\mathrm{CL} / F$ for all patients.

Table 1 Multiple-dose etanercept pharmacokinetic parameters in heart failure patients.

\begin{tabular}{|c|c|c|c|c|c|c|}
\hline Patient & Dose (mg) & $C_{\max }\left(m g l^{-1}\right)$ & $t_{\max }(h)$ & $A U C\left(m g l^{-1} h\right)$ & $C L / \mathrm{F}\left(m l h^{-1}\right)$ & $C_{\mathrm{o}}\left(m g l^{-1}\right)$ \\
\hline 120 & 21.96 & 2.34 & 72 & $192 \star$ & 114 & 1.90 \\
\hline 124 & 25.00 & 2.66 & 24 & 221 & 113 & 1.83 \\
\hline 125 & 25.00 & 3.72 & 36 & $263^{\star}$ & 95.1 & 1.39 \\
\hline 126 & 21.60 & 3.61 & 96 & 269 & 80.4 & 2.18 \\
\hline 129 & 18.24 & 2.13 & 96 & 105 & 174 & 0.69 \\
\hline 130 & 25.00 & 1.39 & 36 & $111 \star$ & 225 & 0.96 \\
\hline 132 & 24.72 & 2.38 & 36 & 207 & 119 & 1.77 \\
\hline 136 & 25.00 & 2.20 & 12 & 128 & 196 & 1.41 \\
\hline 138 & 25.00 & 1.41 & 36 & $109 \star$ & 229 & 1.10 \\
\hline 143 & 22.32 & 2.42 & 24 & 198 & 113 & 1.57 \\
\hline 145 & 25.00 & 1.50 & 36 & 123 & 204 & 0.64 \\
\hline Mean & & 2.34 & 46 & 175 & 138 & 1.40 \\
\hline s.d. & & 0.79 & 29 & 62 & 44 & 0.51 \\
\hline
\end{tabular}

*Time discrepancies in $96 \mathrm{~h}$ sample; AUC extrapolated from $72 \mathrm{~h}$. 
Pharmacokinetic parameters for etanercept are shown in Table 1. Concentrations measured prior to dose administration $\left(C_{\mathrm{o}}\right)$ are also reported.

Etanercept was generally well tolerated in the patients studied [7]. Mild, injection-site reactions were the primary adverse events related to study drug administration. These occurred in $10 \%$ of patients treated with etanercept on at least one occasion, and disappeared after the first month.

This publication provides the first pharmacokinetic data for etanercept in patients with heart failure. The very small number of patients studied limit this report to a preliminary estimate of true parameter values, but the $\mathrm{CL} / F$ values reported here are similar to those reported for healthy volunteers and patients with rheumatoid arthritis after single doses.

\section{Ozlem Soran,' Arthur M. Feldman,' \\ Virginia M. Schneider,' Roberta Hanna, ${ }^{2}$ Douglas L. Mann ${ }^{3}$ \& Joan M. Korth-Bradley}

The ${ }^{1}$ Cardiovascular Institute of the University of Pittsburgh, Pittsburgh, $P A ;{ }^{2}$ Immunex Corporation, Seattle, WA; ${ }^{3}$ the Veterans' Administration Medical Center, Baylor College of Medicine, Houston, TX and

${ }^{4}$ Wyeth-Ayerst Research, Philadelphia, PA, USA

Received 5 July 2000, accepted 17 November 2000

Correspondence: Dr J. M. Korth-Bradley, Wyeth-Ayerst Research, PO Box 42528, Philadelphia, PA 19101, USA. Tel.: -(610) 341-2914; Fax: -(610) 989-4574; E-mail: korthbj@war.wyeth.com

\section{References}

1 Levine B, Kalman J, Mayer L, Fillit HM, Packer M. Elevated circulating levels of tumor necrosis factor in severe chronic heart failure. N Engl J Med 1990; 223: 236-241.

2 Torre-Amione G, Kapadia S, Benedict C, Oral H, Young JB, Mann DL. Proinflammatory cytokine levels in patients with depressed left ventricular ejection fraction: a report from the studies of left ventricular dysfunction (SOLVD). J Am Coll Cardiol 1996; 27: 1201-1206.

3 Jarvis B, Faulds D. Etanercept. A review of its use in rheumatoid arthritis. Drugs 1999; 57: 945-966.

4 Korth-Bradley JM, Rubin AS, Hanna RK, et al. The pharmacokinetics of etanercept in healthy volunteers. Ann Pharmacother 2000; 34: 161-164.

5 Shammas FV, Dickstein K. Clinical pharmacokinetics in heart failure: an updated review. Clin Pharmacokin 1988; 15: 94-113.

6 Johnston D, Duffin D. Drug-patient interactions and their relevance in the treatment of heart failure. Am J Cardiol 1992; 70: 109C-12C.

7 Bozkurt B, Torre-Amione G, Soran OZ, et al. Results of a multidose phase 1 trial with Enbrel (Etanercept, p75 TNF receptor fusion protein) in patients with heart failure. Abstracts of American Heart Association 1999; number 1110-14.

8 Jusko WJ. Guidelines for collection and analysis of pharmacokinetic data. In Applied Pharmacokinetics: Principles of Therapeutic Drug Monitoring 3rd edn, eds Evans WE, Schentag JJ, Jusko WJ, Spokane WA. Applied Therapeutics, 1992; 2-1-2-43.

\section{Non-responders in clinical pharmacology - a commentary to a book review by D.N. Bateman}

The British Journal of Clinical Pharmacology has reviewed 'A Guide to Training in Clinical Pharmacology in Europe' compiled by Professor Kim Brøsen, published by Odense University Press, ISBN 87-7838-459-1 [1], and also available on the EACPT (European Association of Clinical Pharmacology) homepage: http://http:// www.ou.dk/med/homepages/eacpt/eacpt5.html.

Bateman notes that only about half of the European centres in clinical pharmacology have contributed to this first edition, the exact figure being 63\% (Table 1). In the preface to the European guide, Michael Orme, honorary secretary of EACPT, and I write: 'The guide aims to be comprehensive, and if it occasionally fails in that aim, the blame should not be attributed to the Danish office. In some cases it has proved remarkably difficult to persuade senior colleagues to describe their department for the benefit of future generations'.

The editorial office was assisted by the national delegates of EACPT in each country in its attempts to get a complete picture of clinical pharmacology centres in Europe. Reminders by letters and telephone calls were often in vain. The compliance figures (Table 1) may reflect different attitudes to the importance of European collaboration but poor responders can still submit information about their centres to our homepage. Over

Table 1

\begin{tabular}{lccc}
\hline & $\begin{array}{c}\text { Number of } \\
\text { centres asked } \\
\text { to contribute }\end{array}$ & $\begin{array}{c}\text { Number of } \\
\text { centres } \\
\text { Cesponding }\end{array}$ & \% responders \\
\hline Countries & 81 & 81 & 100 \\
$\begin{array}{l}\text { Estonia, Denmark, France, } \\
\text { Germany, Israel, Slovenia, }\end{array}$ & & & \\
$\begin{array}{l}\text { Sweden, Yugoslavia } \\
\text { Austria, Turkey }\end{array}$ & 12 & 9 & 75 \\
$\begin{array}{l}\text { Belgium, Italy, } \\
\text { Spain, UK }\end{array}$ & 78 & 41 & 53 \\
$\begin{array}{l}\text { Finland, Greece, } \\
\text { Hungary, Poland, } \\
\text { Portugal, Russia, }\end{array}$ & 32 & 11 & 34 \\
$\begin{array}{l}\text { Switzerland } \\
\text { Belgium, Czech Republic, } \\
\text { The Netherlands, }\end{array}$ & 31 & 6 & \\
$\begin{array}{l}\text { Norway, Romania } \\
\text { Total }\end{array}$ & & & \\
\hline
\end{tabular}


all it is satisfactory that we now have a description of 148 training centres in clinical pharmacology in Europe.

Our difficulties are similar to those being faced by organisers of international congresses and meetings in clinical pharmacology, who often complain about nonresponders. Without a controlled study it is difficult to know whether this is a problem specific to Clinical Pharmacologists or, more likely perhaps, to the whole area of academic medicine. The increasing pressure on scientists, particularly in the overwhelming need to publish research in highly cited journals, is leading to a neglect of the more philanthropic aspects of academic life. Perhaps a way to reverse this decline would be to publish the names of 'non-responders' in the proceedings of our national and international meetings. This would serve as an early warning system for those colleagues who are involved in society orientated clinical pharmacology. I confess to having been a poor responder in the past, but after many years as chairman of EACPT I have been converted. To paraphrase a US President 'Do not ask what Clinical Pharmacology can do for you but what you can do for Clinical Pharmacology'.

\section{Folke Sjöqvist}

Chairman of EACPT, 1993-99, Karolinska Institute, Department of Clinical Pharmacology, Huddinge University Hospital, S-141-86 Stockholm, Sweden

Received 11 April 2000, accepted 8 November 2000.

Correspondence: Professor Folke Sjöqvist, Karolinska Institute, Department of Clinical Pharmacology, Huddinge University Hospital, S-141-86 Stockholm, Sweden

\section{Reference}

1 Bateman DN. A guide to training in Clinical Pharmacology in Europe. (Book review). Br J Clin Pharmacol 1999;48: 765. 